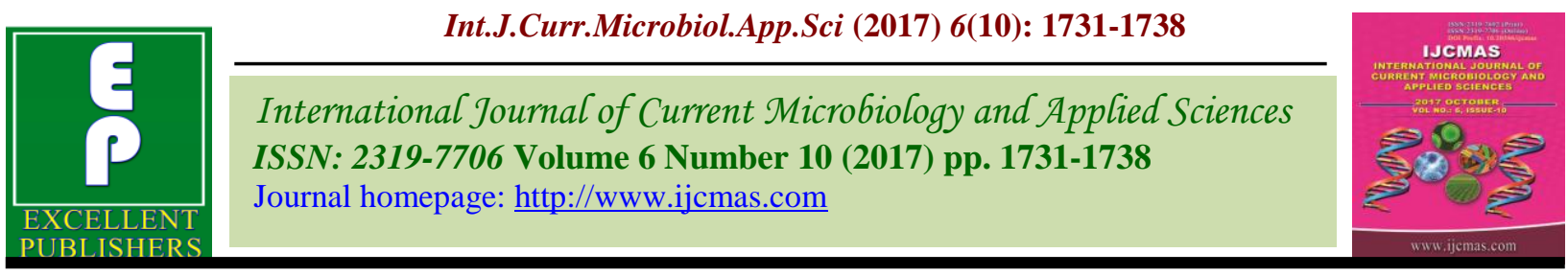

Original Research Article

https://doi.org/10.20546/ijcmas.2017.610.209

\title{
Influence of Irrigation Schedule on the Biological Parameters of TSSM T. urticae Koch. on Okra, Eggplant and Tomato
}

\author{
B. Poovizhiraja*, C. Chinniah and A. Ravikumar \\ Department of Agricultural Entomology, Agricultural College and Research Institute, \\ Madurai - 625 104, Tamil Nadu Agricultural University, Tamil Nadu, India \\ *Corresponding author
}

\section{A B S T R A C T}

\begin{tabular}{|l|}
\hline Ke y w o r d s \\
Biology of TSSM, \\
Host plants of mite, \\
Impacts of moisture \\
regime, \\
Tetranychus \\
urticae.
\end{tabular}

\section{Introduction}

Two-spotted spider mite (TSSM) Tetranychus urticae Koch (Acari: Tetranychidae) is the most economically important plant-feeding pest mite in the world (Van Leeuwen et al., 2013). T. urticae is a generalist feeder and is among the most polyphagous arthropod herbivores (Agrawal 2000), feeding on more than 1,100 plant species belonging to more than 140 different plant families, including those that are known to produce toxic compounds. $T$. urticae threatens greenhouse production and field, vine, and orchard crops, destroying economically important annual and perennial crops worldwide such as tomatoes, peppers, cucumbers, strawberries, corn, apples, grapes, hops, almonds, peppermint, and citrus (Jeppson et al., 1975). $T$. urticae an assemblage of web spinning mites collectively called spider mites. Spider mites (larvae, nymphs, and adults) produce webs from silk glands located at each palp, hence the root of the 'spider' in the common name. Webbing may be used to protect against factors including wind and rain, natural enemies, and exposure to chemicals; for instance, spray droplets may become trapped in a barrier of webbing and fail to contact the mites (Davis, 1952). Silk webbing is used for a variety of different functions including dispersal, colony establishment, 
pheromone communication, adhesion to leaf substrate during quiescence (Gerson 1985), and it can play a role in mating (Penman and Cone 1972). T. urticae is generally known to be active on the underside of leaves, except under high population density. Crops with symptoms of spider mite infestations include a specking appearance and discoloration. Spider mites damage their host plants while feeding, using specialized piercing-sucking, stylet-like mouthparts to penetrate through the outer epidermal cells and into parenchyma cells (Park and Lee 2002), and thus removing chlorophyll and other cell contents. The loss of chlorophyll results in a visibly patchy discoloration of leaf tissue, as well as a reduced photosynthetic rate and production of nutrients. Economic injury occurs as high populations accumulate and feeding increases, leading to sufficient damage over a period of days. Extreme levels of damage can eventually cause leaf and fruit loss, complete defoliation, and death of the host plant. Soil moisture and irrigation have been shown to influence mite feeding in almonds as well as fruit size and yield in strawberries (Dwyer et al., 1987). Mellors et al., (1984) observed that spider mite populations on soybeans decreased on water stressed plants, although the correlation between population intensity and level of water stress was not statistically significant. English-Loeb (1989), studying mites on chamber-reared garden beans, found a bimodal response of mite populations to plant drought stress, with well-irrigated and moderately stressed plants associated with greatest mite reproductive rates. In contrast, mild or severe drought stress reduced mite fecundity. In one of the experiments, soybean water status found to affect the abundance of adult mites. Further analysis of the effects of water-stressed soybean on mites requires details on the life history, population dynamics and behaviour of mites (Kennedy and Smitley, 1985). In a number of studies covering a wide water stress intensity range it has been shown that: 1. mite fecundity is affected by plant water status, and 2 . mites develop faster on water-stressed hosts due to their increased foliar temperature (Oi et al., 1989).

Our research goals were to study different irrigation schedules to determine how this factor influence the reproduction, population buildup and development of two spotted spider mite on various host plants okra, eggplant and tomato.

\section{Materials and Methods}

\section{Biology of $T$. urticae Koch on okra, eggplant and tomato}

Pot culture experiments were conducted at insectary, Department of Agricultural Entomology, Agricultural College and Research Institute, pot culture studies with different watering frequency $\left(\mathrm{T}_{1}-\right.$ Daily irrigation, $\mathrm{T}_{2}-$ Once in a week, $\mathrm{T}_{3}-$ Twice in a week compared with an untreated control) applied to various preferred host plants viz., okra Abelmoschus esculentus (L.) Moench, eggplant Solanam melongena (L.) and tomato Lycopersicon esculentum Mill of T. urticae. Treated plant leaves were collected from each host plants for study the biology and population buildup of $T$. urticae Koch under laboratory condition in Acarology Laboratory, Department of Agricultural Entomology, Agricultural College and Research Institute, Madurai during 2015 to test the irrigation schedules on the biology of TSSM T. urticae Koch. on various host plants (okra, eggplant and tomato) in in-vitro conditions at $27 \pm 2^{\circ} \mathrm{C}$, $70 \pm 5 \%$ relative humidity. In this regard, a pair of male and female were selected from the stock culture and transferred to a fresh leaf disc of each host plants. Fresh leaf discs of each host plants were made which were square or circular in shape. The leaf discs were placed on cotton bed in petridish plate 
facing under surface upward. The cotton bed kept wet by soaking with water twice daily so that the leaf discs remained fresh. Twenty four hours later, the eggs laid were collected from these leaf discs and individually transferred with a fine camel hair brush onto new leaf discs of respective hosts. All the transferred eggs and subsequent stages (larva, nymphs and adult) were carefully monitored daily until reaching adulthood and their survival and moulting to the next stage were recorded. As soon as the adults emerged, the females were differentiated by their round caudal end against male with pointed caudal ends. Based on these observations apart from the hatchability of eggs were calculated immature survivorship and the sex ratio.

\section{Results and Discussion}

The biology of TSSM T. urticae was studied on okra Abelmoschus esculentus (L.) Moench, eggplant Solanam melongena (L.) and tomato Lycopersicon esculentum Mill with different watering frequency $\left(\mathrm{T}_{1}-\right.$ Daily irrigation, $\mathrm{T}_{2}$ - Once in a week, $\mathrm{T}_{3}$ - Twice in a week compared with an untreated control) the results revealed that. Comparing the different developmental stages on okra it could be observed that the egg period was least in $\mathrm{T}_{1}$ (2.4 days) which was on par with $\mathrm{T}_{2}$ (2.5 days) and $\mathrm{T}_{3}$ (3.5 days) compared to untreated control (4.2 days). The larval duration was also comparatively shorter in $\mathrm{T}_{1}$ (1.2 days) followed by $\mathrm{T}_{2}$ (1.4 days), $\mathrm{T}_{3}$ (1.5 days) which was on par with untreated control? The protonymphal period was less in $\mathrm{T}_{1}$ (1.1 days) which was on par with $\mathrm{T}_{2}$ (1.2 days) followed by $\mathrm{T}_{3}$ (1.4 days) and compared to untreated control (1.8 days). So also the duetonymphal period was significantly shorter in $\mathrm{T}_{3}(1.3$ days) followed by $\mathrm{T}_{1}$ (1.4 days), $\mathrm{T}_{2}$ (1.5 days) and compared to untreated control (1.9 days).

As for as adult longevity of $\delta^{\lambda}$ mite is concerned the duration was shorter in $\mathrm{T}_{1}(9.2$ days) which was on par with $\mathrm{T}_{2}$ (9.5 days) followed by $T_{3}$ (10.3 days) and compared to untreated control (11.2 days). With reference to $q$ mites the adult longevity was the shortest in $\mathrm{T}_{3}$ (12.5 days) which was statistically on par with $\mathrm{T}_{1}$ (12.8 days) followed by $\mathrm{T}_{2}$ (13.3 days) and compared to over untreated control (15.1 days). The pre-oviposition period was also significantly shorter in $\mathrm{T}_{1}$ (0.8 days) followed by $T_{2}$ (1.1 days) and $T_{3}$ (1.4 days) and compared to untreated control (1.7 days).

Oviposition period was relatively longer in $T_{1}$ (18.1 days) followed by $\mathrm{T}_{2}$ (15.4 days) and $\mathrm{T}_{3}$ (14.4 days) which was on par with untreated control (14.3 days). So also the postoviposition period was the least in $\mathrm{T}_{1}$ (1.1 days) which was on par with $\mathrm{T}_{2}$ (1.2 days) followed by $\mathrm{T}_{3}$ (1.5 days) and compared to untreated control (1.8 days). The fecundity rate was the highest in $\mathrm{T}_{1}$ (122 eggs/ 9 ) followed by $\mathrm{T}_{2}(97 \mathrm{eggs} / \mathrm{Q})$ and $\mathrm{T}_{3}$ (82 eggs/ + ) and compared to untreated control (80 eggs/ + ). The hatching percentage was also maximum in $\mathrm{T}_{1}(87.70 \%)$ followed by $\mathrm{T}_{2}$ $(86.60 \%), \mathrm{T}_{3}(85.37 \%)$ and over the control $(82.50 \%)$. The sex ratio $\left(\delta:\right.$ 우) was more in $\mathrm{T}_{1}$ (1:4.60) followed by $\mathrm{T}_{2}(1: 4.38), \mathrm{T}_{3}(1: 2.67)$ and compared to untreated control $(1: 2.45)$. The severity of webbing was intense in $T_{1}$ which was on par with $T_{2}$, moderate in $T_{3}$ and it was mild in untreated control as the population of mite was very fewer in number.

In eggplant the different developmental stages of $T$. urticae was observed that the egg period was the least in $T_{1}$ (2.5 days) followed by $T_{2}$ (2.9 days) which was on par with $\mathrm{T}_{3}$ and compared to untreated control (3.2 days). The larval duration was relatively shorter in $T_{1}$ (1.2 days) which was on par with $\mathrm{T}_{2}$ followed by $\mathrm{T}_{3}$ (1.5 days) and compared to untreated control (1.9 days). Protonymphal period and duetonymphal period were shorter in $\mathrm{T}_{1}$ and on par with $\mathrm{T}_{2}$ followed by $\mathrm{T} 3$. With reference to adult longevity the $\hat{\sigma}$ had a duration of (10.2 days) in $\mathrm{T}_{1}$ on par with $\mathrm{T}_{2}$ (10.5 days) and $\mathrm{T}_{3}$ (11.7 days) and compared 
to untreated control (12.5 days). With reference to $q$ adult longevity was the shortest $\mathrm{T}_{1}$ (13.1 days) which was on par with $\mathrm{T}_{2}$ (13.5 days), $\mathrm{T}_{3}$ (14.0 days) and compared to untreated control (15.1 days). Preoviposition period and post-oviposition period were shorter in $T_{1}$ followed by $T_{2}$ and $T_{3}$. Oviposition period was relatively longer in $T_{1}$ (17.5 days) which was on par with $\mathrm{T}_{2}$ (17 days) followed by) $\mathrm{T}_{3}$ (16.5 days) and compared to untreated control (14.5 days). The fecundity rate was the highest in $\mathrm{T}_{1}(110$ eggs/ + ) followed by $\mathrm{T}_{2}\left(95\right.$ eggs/ + ) and $\mathrm{T}_{3}$ (89 eggs/ $/$ ) which was on par with untreated control (66 eggs/ $q$ ). Hatching percentage was also maximum in $\mathrm{T}_{1}(90.00 \%)$ followed by $\mathrm{T}_{2}$ (87.37\%), $\mathrm{T}_{3}(85.39 \%)$ and compared to untreated control (78.79\%). Sex ratio ( $\delta^{\lambda}:$ 우) was more in $T_{1}$ (1:4.43) followed by $T_{2}$ (1:3.61), $\mathrm{T}_{3}$ (1:3.33) and compared to un treated control (1:3.13). The severity of webbing was intense in $T_{1}$ and on par with $T_{2}$ followed by moderate in $T_{3}$ and untreated control.

Observing the various developmental stages on tomato it could be perceived that the egg period was significantly shorter in $\mathrm{T}_{3}(2.3$ days) on par with $\mathrm{T}_{1}$ (2.3 days) followed by $\mathrm{T}_{2}$ (2.7 days) and compared to untreated control (3.3 days). The larval duration was comparatively shorter in $\mathrm{T}_{1}$ (1.2days) followed by $\mathrm{T}_{2}$ (1.3 days), $\mathrm{T}_{3}$ (1.5 days) and compared to untreated control (1.8 days). The protonymphal period was least in $\mathrm{T}_{1}(1.2$ days) followed by $T_{2}$ (1.3days), $T_{3}$ (1.6 days) and compared to untreated control (1.7 days). The duetonymphal period, adult longevity, pre-oviposition period and post-oviposition period also showed similar trend.

The oviposition period was relatively longer and fecundity rate was maximum in $\mathrm{T}_{1}(107$ eggs/ $/$ ) followed by $\mathrm{T}_{2}\left(96\right.$ eggs/ $/$ ) and $\mathrm{T}_{3}$ (84 eggs $/ \%$ ) and compared to untreated control (72 eggs/ + ). The hatching percentage was also maximum in $\mathrm{T}_{1}(89.72 \%)$ followed by $\mathrm{T}_{2}(85.42 \%), \mathrm{T}_{3}(83.33 \%)$ and compared to

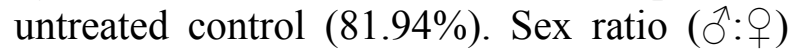
was more in $T_{1}$ (1:3.00) followed by $T_{2}$ (1:2.90), $\mathrm{T}_{3} \quad(1: 2.89)$ and compared to untreated control (1:2.69). Webbing intensity was moderate in $T_{1}$ and $T_{2}$ followed by very light webbing in $\mathrm{T}_{3}$ and untreated control. Thus all the biological parameters were favourable in $\mathrm{T}_{1}$ indicating that daily irrigation is the most suitable moisture regime which supported as many numbers of $T$. urticae population by maintaining the cell turgor pressure and succulence of leaf which in turn encouraged the uninterrupted feeding activity, which is most suitable for other biological parameters (Table 1).

The results revealed that among the three different watering schedules viz., (Daily irrigation, once in a week and twice in a week compared with an untreated control) significantly influenced all the developmental stages of T. urticae on host plants viz., okra, eggplant, and tomato tested. In the present study it is clear that all the biological parameters of TSSM viz., egg period, larval period, protonymphal period, duetonymphal period, adult longevity, pre-oviposition period and post-oviposition period were the shortest in daily irrigation schedule followed by once in a week and twice in a week. The oviposition period, fecundity, hatching percentage, sex ratio and webbing intensity was found to be more in daily irrigation followed by once in a week. Thus all the biological parameters were favourable in daily irrigation followed by once in a week indicating that daily irrigation is the most suitable moisture regime which supported as many number of $T$. urticae population probably by maintaining the cell turgor pressure and succulency of leaf which inturn encouraged the uninterrupted feeding process, which is most suitable for other biological parameters (Table 2). 
Table.1 Influence of irrigation schedule on the biological parameters of TSSM T. urticae Koch. on okra, eggplant and tomato

\begin{tabular}{|c|c|c|c|c|c|c|c|}
\hline \multirow{3}{*}{ Host plants } & \multirow{3}{*}{ Watering frequency } & \multicolumn{6}{|c|}{ Duration in days (Mean $* \pm$ S.D.) } \\
\hline & & \multirow{2}{*}{ Egg } & \multirow{2}{*}{ Larva } & \multirow{2}{*}{ Protonymph } & \multirow{2}{*}{ Duetonymph } & \multicolumn{2}{|c|}{ Adult longevity } \\
\hline & & & & & & $\hat{0}$ & q \\
\hline \multirow{6}{*}{ Okra } & $T_{1}$-Daily irrigation & $2.4 \pm 0.09^{\mathrm{a}}$ & $1.2 \pm 0.02^{\mathrm{a}}$ & $1.1 \pm 0.02^{\mathrm{a}}$ & $1.3 \pm 0.02^{\mathrm{a}}$ & $9.2 \pm 0.11^{\mathrm{a}}$ & $12.5 \pm 0.51^{\mathrm{a}}$ \\
\hline & $T_{2}$-Once in a week & $2.5 \pm 0.03^{\mathrm{a}}$ & $1.4 \pm 0.05^{\mathrm{b}}$ & $1.2 \pm 0.01^{\mathrm{b}}$ & $1.4 \pm 0.05^{\mathrm{b}}$ & $9.5 \pm 0.25^{\mathrm{b}}$ & $12.8 \pm 0.73^{\mathrm{a}}$ \\
\hline & $T_{3}$-Twice in a week & $3.5 \pm 0.10^{\mathrm{b}}$ & $1.5 \pm 0.05^{\mathrm{c}}$ & $1.4 \pm 0.03^{\mathrm{c}}$ & $1.5 \pm 0.05^{\mathrm{c}}$ & $10.3 \pm 0.32^{\mathrm{c}}$ & $13.3 \pm 0.78^{\mathrm{b}}$ \\
\hline & Untreated control & $4.2 \pm 0.03^{\mathrm{c}}$ & $1.5 \pm 0.02^{\mathrm{c}}$ & $1.8 \pm 0.03^{\mathrm{d}}$ & $1.9 \pm 0.05^{\mathrm{d}}$ & $11.2 \pm 0.25^{\mathrm{d}}$ & $15.1 \pm 0.59^{\mathrm{c}}$ \\
\hline & SEd & 0.0359 & 0.0133 & 0.022 & 0.0149 & 0.0187 & 0.1949 \\
\hline & $\mathrm{CD}(\mathrm{P}=0.05)$ & 0.0782 & 0.0289 & 0.0479 & 0.0324 & 0.0407 & 0.4246 \\
\hline \multirow{6}{*}{ Eggplant } & $T_{1}$-Daily irrigation & $2.5 \pm 0.09^{\mathrm{a}}$ & $1.2 \pm 0.02^{\mathrm{a}}$ & $1.1 \pm 0.04^{\mathrm{a}}$ & $1.2 \pm 0.04^{\mathrm{a}}$ & $10.2 \pm 0.18^{\mathrm{a}}$ & $13.1 \pm 0.38^{\mathrm{a}}$ \\
\hline & $T_{2}$-Once in a week & $2.9 \pm 0.03^{\mathrm{b}}$ & $1.2 \pm 0.04^{\mathrm{a}}$ & $1.2 \pm 0.01^{\mathrm{b}}$ & $1.3 \pm 0.06^{\mathrm{b}}$ & $10.5 \pm 0.46^{\mathrm{a}}$ & $13.5 \pm 0.68^{\mathrm{a}}$ \\
\hline & $T_{3}$-Twice in a week & $2.9 \pm 0.13^{\mathrm{b}}$ & $1.5 \pm 0.05^{\mathrm{b}}$ & $1.5 \pm 0.05^{\mathrm{c}}$ & $1.6 \pm 0.01^{\mathrm{c}}$ & $11.7 \pm 0.50^{\mathrm{b}}$ & $14.0 \pm 0.17^{\mathrm{b}}$ \\
\hline & Untreated control & $3.2 \pm 0.08^{c}$ & $1.9 \pm 0.03^{\mathrm{c}}$ & $1.6 \pm 0.03^{\mathrm{d}}$ & $1.8 \pm 0.05^{\mathrm{d}}$ & $12.5 \pm 0.53^{\mathrm{c}}$ & $15.1 \pm 0.36^{\mathrm{c}}$ \\
\hline & SEd & 0.0439 & 0.0133 & 0.0198 & 0.0125 & 0.1546 & 0.1925 \\
\hline & $\mathrm{CD}(\mathrm{P}=0.05)$ & 0.0955 & 0.0375 & 0.0432 & 0.0272 & 0.335 & 0.4195 \\
\hline \multirow{6}{*}{ Tomato } & $\mathrm{T}_{1}$-Daily irrigation & $2.3 \pm 0.05^{\mathrm{a}}$ & $1.2 \pm 0.06^{\mathrm{a}}$ & $1.2 \pm 0.04^{\mathrm{a}}$ & $1.4 \pm 0.04^{\mathrm{a}}$ & $9.8 \pm 0.47^{\mathrm{a}}$ & $12.3 \pm 0.57^{\mathrm{a}}$ \\
\hline & $T_{2}$-Once in a week & $2.3 \pm 0.10^{\mathrm{a}}$ & $1.3 \pm 0.04^{\mathrm{b}}$ & $1.3 \pm 0.01^{\mathrm{b}}$ & $1.5 \pm 0.03^{\mathrm{b}}$ & $10.5 \pm 0.45^{\mathrm{b}}$ & $12.5 \pm 0.68^{\mathrm{a}}$ \\
\hline & $T_{3}$-Twice in a week & $2.7 \pm 0.12^{\mathrm{b}}$ & $1.5 \pm 0.02^{\mathrm{b}}$ & $1.6 \pm 0.06^{\mathrm{c}}$ & $1.7 \pm 0.03^{\mathrm{c}}$ & $11.4 \pm 0.25^{\mathrm{c}}$ & $13.2 \pm 0.69^{\mathrm{b}}$ \\
\hline & Untreated control & $3.3 \pm 0.09^{\mathrm{c}}$ & $1.8 \pm 0.06^{\mathrm{c}}$ & $1.7 \pm 0.02^{\mathrm{d}}$ & $1.9 \pm 0.01^{\mathrm{d}}$ & $11.5 \pm 0.54^{\mathrm{c}}$ & $15.3 \pm 0.64^{\mathrm{c}}$ \\
\hline & SEd & 0.0423 & 0.015 & 0.0155 & 0.0155 & 0.1151 & 0.1574 \\
\hline & $\mathrm{CD}(\mathbf{P}=0.05)$ & 0.0157 & 0.0326 & 0.0337 & 0.0337 & 0.2507 & 0.3429 \\
\hline
\end{tabular}

*Each value is the mean of four replications.

In a column, mean \pm S.D. followed by common superscript(s) are at par by LSD (P=0.05), Abbreviations: $\widehat{\alpha}$ - Male; $q$ - Female. 
Table.2 Pre-oviposition, oviposition, post-oviposition periods, fecundity (No.of eggs / 9 ), hatching \%, sex ratio and webbing intensity of TSSM, T. urticae on okra, eggplant and tomato

\begin{tabular}{|c|c|c|c|c|c|c|c|c|}
\hline \multirow[t]{2}{*}{ Host plants } & \multirow{2}{*}{ Watering frequency } & \multicolumn{3}{|c|}{ Duration in days (Mean* \pm S.D.) } & \multirow{2}{*}{$\begin{array}{c}\text { Fecundity (No.of eggs } / \not), \\
\text { (Mean* } \pm \text { S.D.) }\end{array}$} & \multirow{2}{*}{$\begin{array}{c}\text { Hatching } \\
\%\end{array}$} & \multirow{2}{*}{$\begin{array}{c}\text { Sex ratio } \\
(\lesssim: \bigcirc)\end{array}$} & \multirow{2}{*}{$\begin{array}{l}\text { Webbing } \\
\text { intentsity }\end{array}$} \\
\hline & & Pre-oviposition & Oviposition & Post-oviposition & & & & \\
\hline \multirow{6}{*}{ Okra } & $\mathbf{T}_{1}$-Daily irrigation & $0.8 \pm 0.08^{\mathrm{a}}$ & $18.1 \pm 0.43^{\mathrm{a}}$ & $1.1 \pm 0.05^{\mathrm{a}}$ & $122 \pm 5.17^{\mathrm{a}}$ & 87.70 & $1: 4.60$ & S \\
\hline & $T_{2}$-Once in a week & $1.1 \pm 0.03^{\mathrm{b}}$ & $15.4 \pm 0.26^{\mathrm{b}}$ & $1.2 \pm 0.01^{\mathrm{b}}$ & $97 \pm 2.27^{b}$ & 86.60 & $1: 4.38$ & $\mathrm{~S}$ \\
\hline & $T_{3}$-Twice in a week & $1.4 \pm 0.03^{\mathrm{c}}$ & $14.4 \pm 0.34^{\mathrm{c}}$ & $1.5 \pm 0.06^{\mathrm{c}}$ & $82 \pm 2.95^{\mathrm{c}}$ & 85.37 & $1: 2.67$ & MS \\
\hline & Untreated control & $1.7 \pm 0.05^{\mathrm{d}}$ & $14.3 \pm 0.36^{\mathrm{c}}$ & $1.8 \pm 0.04^{\mathrm{d}}$ & $80 \pm 2.24^{c}$ & 82.50 & $1: 2.45$ & $\mathrm{~L}$ \\
\hline & SEd & 0.0174 & 0.0982 & 0.0271 & 1.5096 & - & - & - \\
\hline & $\mathrm{CD}(\mathrm{P}=0.05)$ & 0.0379 & 0.214 & 0.0591 & 3.2892 & - & - & - \\
\hline \multirow{6}{*}{ Eggplant } & $T_{1}$-Daily irrigation & $1.0 \pm 0.06^{\mathrm{a}}$ & $17.5 \pm 0.60^{\mathrm{a}}$ & $1.1 \pm 0.02^{\mathrm{a}}$ & $110 \pm 3.12^{\mathrm{a}}$ & 90.00 & $1: 4.43$ & $\mathrm{~S}$ \\
\hline & $\mathbf{T}_{2}$-Once in a week & $1.2 \pm 0.06^{\mathrm{b}}$ & $15.5 \pm 0.66^{\mathrm{ab}}$ & $1.4 \pm 0.03^{b}$ & $95 \pm 1.69^{b}$ & 87.37 & $1: 3.61$ & $\mathrm{~S}$ \\
\hline & $T_{3}$-Twice in a week & $1.6 \pm 0.07^{\mathrm{c}}$ & $15.2 \pm 0.28^{\mathrm{a}}$ & $1.7 \pm 0.07^{\mathrm{c}}$ & $89 \pm 2.18^{c}$ & 85.39 & $1: 3.33$ & MS \\
\hline & Untreated control & $1.8 \pm 0.02^{\mathrm{d}}$ & $14.5 \pm 0.80^{\mathrm{c}}$ & $1.7 \pm 0.05^{\mathrm{c}}$ & $66 \pm 2.35^{c}$ & 78.79 & $1: 3.13$ & MS \\
\hline & SEd & 0.0242 & 0.2887 & 0.0221 & 0.0083 & - & - & - \\
\hline & $\mathrm{CD}(\mathrm{P}=0.05)$ & 0.0528 & 0.6289 & 0.0482 & 0.0181 & - & - & - \\
\hline \multirow{6}{*}{ Tomato } & $T_{1}$-Daily irrigation & $1.1 \pm 0.15^{\mathrm{a}}$ & $17.2 \pm 0.75^{\mathrm{a}}$ & $1.2 \pm 0.03^{\mathrm{a}}$ & $107 \pm 3.29^{\mathrm{a}}$ & 89.72 & $1: 3.00$ & MS \\
\hline & $T_{2}$-Once in a week & $1.4 \pm 0.12^{b}$ & $16.5 \pm 0.35^{\mathrm{b}}$ & $1.5 \pm 0.01^{\mathrm{b}}$ & $96 \pm 3.24^{b}$ & 85.42 & $1: 2.90$ & MS \\
\hline & $\mathbf{T}_{3^{-}}$Twice in a week & $1.7 \pm 0.09^{\mathrm{c}}$ & $15.5 \pm 0.33^{\mathrm{c}}$ & $1.5 \pm 0.04^{\mathrm{b}}$ & $84 \pm 4.98^{c}$ & 83.33 & $1: 2.89$ & $\mathrm{~L}$ \\
\hline & Untreated control & $1.8 \pm 0.19^{\mathrm{d}}$ & $13.9 \pm 0.63^{d}$ & $1.9 \pm 0.08^{\mathrm{c}}$ & $72 \pm 3.25^{\mathrm{d}}$ & 81.94 & $1: 2.69$ & $\mathrm{~L}$ \\
\hline & SEd & 0.0223 & 0.2136 & 0.0167 & 0.8646 & - & - & - \\
\hline & $\mathrm{CD}(\mathrm{P}=0.05)$ & 0.0487 & 0.4654 & 0.0363 & 1.8838 & - & - & - \\
\hline
\end{tabular}

*Each value is the mean of four replications.

In a column, mean \pm S.D. followed by common superscript(s) are at par by LSD $(\mathrm{P}=0.05)$,

Abbreviations: $\widehat{\partial}$-Male; 우-Female; L- Low webbing; MS-Moderate webbing; S-Severe webbing. 
The time taken for various developmental stages found decreased in different watering frequency on various host plants. According to Oi et al., 1989; Louda and Collingey, 1992; Huberty and Denno (2004) water deficit causes physiological changes in plants, including a reduced synthesis of secondary metabolites or protective compounds, which a negative effect on feeding efficiency of mites, increased content of soluble nitrogen (amino acids, amides) and free sugars, which improves the overall nutritional potential of plant tissues, and the development of mites which contributes to a shorter duration of their individual stages, i.e. eggs, larvae, protonymph, deutonymph and adults.

Mattson and Haack, (1987) who also have published the degree of imposed water stress was substantial importance as mite development was strongly suppressed under heavy drought condition. In contrast, Wilson (1994) who found that the leaf damage per mite was slighter on well-watered plants than on water-stressed plants and importantly, the area of severely damaged leaf was far smaller on well-watered plants. The low ratio of intense damage to overall leaf damage on the well-watered plants contrasts with that observed on water-stressed plants, where mites tend to feed preferentially in protected sites on the leaf surface, spreading only as the damaged area becomes unsuitable.

Hollingsworth and Berry (1982), DeAngelis et al., (1983), Mellors et al., (1984), Youngman and Barnes (1986). OloumiSadeghi et al., (1988) found that water stress reduced the density of mites and especially it influenced the density of females and eggs. And also contrast water deficit that may influence leaf suitability for mites include: more, and qualitatively different, epicuticular waxes that are known to influence herbivory (Eigenbrode and Espelie, 1995); secondly changes in concentration of nutrients and of secondary metabolites in plant tissues, often invoked to explain differences in herbivore responses to host plant moisture status. Sadras et al., (1998), according to whom visual symptoms of damage were more pronounced on well-watered plants, where females preferred to feed and lay eggs and waterstressed plants could not affect the density of spider mites. In comparison with unstressed host plants, the abundance of spider mites on water-stressed hosts may increase, decrease or remain unchanged (English-Loeb, 1989). Mite behavior and life parameters are affected by environmental factors, such as temperature, moisture, habitat morphological and chemical components of host plants, especially by the nutrients, such as nitrogen, phosphorus, sugars, amino acids and semiochemicals in host plants and apart from this the host plant moisture regimes factor play key role in influencing the growth / metabolism and rate of development of TSSM on various host plant significantly.

\section{References}

Agrawal, A. A., 2000. Host- range evolution: adaptation and trade- offs in fitness of mites on alternative hosts. Ecology. 81(2), pp. 500-508.

Davis, D. W., 1952. Some effects of DDT on spider mites. Journal of Economic Entomology, 45(6), pp.1011-1019.

De Angelis, J. D., R. E. Berry and G. W. Krantz. 1983. Evidence for spider mite (Acari: Tetranychidae) injury induced leaf water deficits and osmotic adjustment in peppermint. Environmental Entomology, 12, pp.336-339.

Dwyer, L. M., D. W. Stewart, L. Houwing, and D. Balchin. 1987. Response of strawberries to irrigation scheduling. Horticultural Science. 22, pp.42-44.

Eigenbrode, S. D., and K. E. Espelie. 1995. Effects of plant epicuticular lipids on insect herbivores. Annual Review of Entomology, 40, pp.171-194. 
English-Loeb, G. M., 1989. Nonlinear responses of spider mites to drought-stressed host plants. Ecological Entomology. 14, pp.4555.

Gerson, U., 1985. Other predaceous mites and spiders. Spider mites. Their biology, natural enemies and control. Elsevier, Amsterdam, pp.375-384.

Hollingsworh, C. S., and R. E. Berry. 1982. Two spotted spider mite (Acari: Tetranychidae) in peppermint: population dynamics and influence of cultural practices. Environmental Entomology, 11, pp.2801284.

Huberty, A.F., and Denno, R.F. 2004. Plant water stress and its consequences for herbivorous insects: A new synthesis. Ecology, 85, pp.1383-1398.

Jeppson, L. R., H. H. Keifer, and E. W. Baker. 1975. Mites injurious to economic plants. Barkeky Loss Angeles California Press Ltd. London, pp. 298-301.

Kennedy, G. G., and D. R. Smitley. 1985. Dispersal. Spider mites: their biology, natural enemies and control, 1, pp.233-242.

Louda, S. M., and S. K. Collinge. 1992. Plant resistance to insect herbivores: a field test of the environmental stress hypothesis. Ecology, 73(1), pp.153-169.

Mattson, W. J., and R. A. Haack. 1987. The role of drought stress in provoking outbreaks of phytophagous insects (pp. 365-407). In P. Barbosa and J. Schultz (Eds.). Insect Outbreaks: Ecological and Evolutionary Perspectives.

Mellors, W. K., A. Allegro and A. N. Hsu. 1984. Effects of carbofuran and water stress on growth of soybean plants and two spotted spider mite (Acari: Tetranychidae) populations under greenhouse conditions. Environmental entomology, 13(2), pp.561-567.

Oi, D. H., J. P. Sanderson., R. R. Youngman and M. M. Barnes. 1989. Developmental times of the Pacific spider mite (Acari: Tetranychidae) on water-stressed almond trees. Environmental Entomology, 18(2), pp.208-212.

Oloumi-Sadeghi, H., C. G. Helm, M. Kogan and D. F. Schoeneweiss. 1988. Effect of water stress on abundance of two spotted spider mite on soybeans under greenhouse conditions. Entomologia Experimentalis et Applicata, 48, pp.85 -90.

Park, Y. L., and J. H. Lee. 2002. Leaf cell and tissue damage of cucumber caused by two spotted spider mite (Acari: Tetranychidae). Journal of Economic Entomology, 95(5), pp.952-957.

Penman, D. R., and W. W. Cone. 1972. Behavior of male two spotted spider mites 1 in response to quiescent female deutonymphs. Annals of the Entomological Society of America, 65(6), pp.1289-1293.

Sadras, V. O., L. J. Wilson and D. A. Lally. 1998. Water deficit enhanced cotton resistance to spider mite herbivory. Annals of Botany, 81(2), pp.273-286.

Van Leeuwen, T., W. Dermauw, M. Grbic., L. Tirry and R. Feyereisen. 2013. Spider mite control and resistance management: does a genome help? Pest management science, 69(2), pp.156-159.

Wilson, L. J., 1994. Resistance of okra-leaf cotton genotypes to two spotted spider mites (Acari: Tetranychidae). Journal of Economic Entomology, 87(6), pp.17261735 .

\section{How to cite this article:}

Poovizhiraja, B., C. Chinniah and Ravikumar, A. 2017. Influence of Irrigation Schedule on the Biological Parameters of TSSM T. urticae Koch. on Okra, Eggplant and Tomato. Int.J.Curr.Microbiol.App.Sci. 6(10): 1731-1738. doi: https://doi.org/10.20546/ijcmas.2017.610.209 